\title{
The hierarchy of value-based components within the "happiness" concept in the Russian linguistic consciousness
}

\author{
Zhanna Viktorovna Nikonova ${ }^{1 *}$ \\ ${ }^{1}$ Nizhny Novgorod Linguistics University, The Higher School of Linguistics, Pedagogics and \\ Psychology, Department of Theory and Practice of the German Language, Research Laboratory \\ "Artificial Intelligence and Cognitive Research", Nizhny Novgorod, Russia
}

\begin{abstract}
The article considers the value-based component of the "happiness" concept in the Russian language as one of the main concepts in the Russian national consciousness. The study aims at determining and describing the hierarchy of such components in the Russian language. It supplements the current linguistic information about the content of the above-mentioned concept by revealing the hierarchy of its value-based components in the Russian linguistic consciousness. This approach is used to study the "happiness" concept in the Russian language for the first time and proves the scientific novelty of this research. The theoretical basis is formed by postulates of modern cognitive linguistics about concepts as units of a personal conceptual system in their relation to linguistic expressions containing information about the world, as well as concepts as national images (ideas or symbols) complicated by individual representation. The research subject is the hierarchical connections among value-based components of the "happiness" concept in the Russian linguistic consciousness objectified by various verbal means and acting as determinants of the concept's name. The main objective is to identify the hierarchy of value-based components of the above-mentioned concept and reveal its specifics in the Russian linguistic consciousness. The research material consists of the linguistic facts obtained in the course of a freeassociation experiment conducted at the end of January 2021 by questioning users of the social network VKontakte. The questionnaire explained the goals and objectives of the experiment and provided an incentive for an associative array of 10 positions to the concept under study. After analyzing the results of this psycholinguistic experiment, the authors have established that the "happiness" concept in the Russian language has a clear hierarchy of value-based components, which highlights the specific conceptualization of such an abstract category as "happiness" in the linguistic consciousness of native Russian speakers.
\end{abstract}

Keywords: concept, value-based components of the concept, "happiness" concept, linguistic consciousness.

\footnotetext{
*Corresponding author: nikonova67@mail.ru
} 


\section{Introduction}

The full-fledged transformation of the world affects all aspects of human life, tests not only the person's surroundings (environment and society) but also the people themselves and their inner world. Changing values, moral norms, attitudes, behavioral patterns and means of interaction influence the subjective experiences of people, their mental state and a sense of psychological safety. As a result, the concepts of psychological well-being and happy life get a new understanding, which increases the demand for studying the phenomenon of "happiness" from the standpoint of various humanities.

Being a concrete psychological phenomenon as an exclusively "personal experience of the fullness of one's being accompanied by a feeling of deep moral satisfaction with the results of one's life" [1:4], the "happiness" category is quite specific since it includes many conceptual components associated with the subjective perception of a person and the surrounding reality.

According to the Russian linguists, the "schastie" lexeme in Russian has "definite semantics: luck, fate, destiny, well-being... Depending on an assessment, there are two "varieties" or two stages of happiness. The first type means "the absence of evil" and is opposite to unhappiness. The second type is defined as the joy experienced by a person, a positive emotional state caused by a positive assessment of one's destiny, [...] a state of mind that depends on the attitudes and expectations of a person" [2:374].

The relevant scientific literature provides various descriptions of the "happiness" concept in Russian [3-8]. Many scholars emphasize that the concept under study includes a wide range of cognitive features associated with happiness according to native speakers of the Russian language: connection with flora and fauna, natural phenomena, inanimate objects, human being and their personality traits; physically quantities: weight, volume, size, temperature, i.e. happiness can be heard, touched, it has a smell, color and taste. It is associated with universal human values, elusive entities and mundane things that are most significant for a person at a particular moment.

Given the complexity, discreteness and multidimensionality of the concept under study, it would be logical to assume that its value-based components are presented not chaotically but in a certain relationship, which is of particular importance for characterizing the linguistic worldview [9: 16].

\section{Methods}

Being a technique identifying associations that have developed in an individual throughout the previous experience, an association experiment is widely used in psycholinguistics and plays a special role among the methods of reconstructing linguistic consciousness. It gives access to the mental vocabulary and cultural stereotypes of a particular people [10-12] and reveals the semantic connections of words objectively existing in the psyche of native speakers [13: 25].

\section{Results and discussion}

For analysis, we selected spontaneous associations to the "happiness" concept of the first 100 people who took part in the experiment.

The social image of the experiment participants is as follows:

Age: 23 respondents from 17 to 30 years old (23\%), 20 respondents from 31 to 40 years old $(20 \%), 42$ respondents from 41 to 50 years old (42\%), 15 respondents from 51 to 70 years old (15\%). Thus, the experiment participants under 40 years old make up $43 \%$ and those over 
40 years old amount to $57 \%$ of the total number. Their gender was as follows: 88 female respondents $(88 \%)$ and 12 male respondents $(12 \%)$.

The processing of the experiment results confirmed the research hypothesis and gave new impulses for understanding the "happiness" concept in the Russian language.

So what is "happiness" in the linguistic consciousness of the experiment participants? What associations does the "schastie" word evoke in them? What hierarchical connections can be traced in their associations to the concept under study?

While processing the empirical data obtained, we have concluded that the most frequent associations in the first out of ten positions of the associative array were the following determinants of happiness:

- "Love" (20\%), including: through the "lyubov" (18\%), specific figurative and tactile associations with the same meaning: "beloved" (1\%, Julia, 32 years old), "hug" (1\%, Elena, 45 years old);

- "Family" (15\%), including through the "semya" lexeme (6\%) and associative determinants of this concept: "children" (5\%), "my son" (1\%, Irina, 53 years old), "relatives" (1\%, Maksim, 43 years old), "husband" (1\%, Anastasia, 37 years old), "home" (1\%, Anna, 41 years old).

- "Health" (13\%).

Associations combining these images were as follows:

"Love in the family" (1\%, Igor, 57 years old), "healthy family" (1\%, Zhanna, 42 years old).

Thus, $50 \%$ of the respondents associated happiness with such universal human values as love, family and health.

However, we should pay attention to the hierarchical chain of associations presented by the experiment participants.

First of all, we should consider the nuclear group of associations in the first three positions.

The analysis has demonstrated that those participants in the experiment who indicated love as the first association of happiness most often put family $(10 \%)$ or health $(2 \%)$ in the second and third positions in their hierarchy of associations. Those who believed that happiness was family placed love $(8 \%)$ and health $(5 \%)$ in second and third positions, respectively, in the hierarchy of values. Those who connected happiness with health placed love $(4 \%)$ and family $(5 \%)$ in the second and third positions of the hierarchy of their valuebased associations.

In addition, the first three positions of happiness-related associations contained determinants of the same thematic group or basic values of love/family/health, for example: "children - love - home" (Elena, 45 years old); "family - children - love" (Margarita, 21 years old); "family - children - health" (Maria, 22 years old); "husband - children" (Anastasia, 37 years old); "love - family - children" (Marina, 41 years old); "home - children - love" (Anna, 41 years old); "children - living parents - beloved woman" (Mikhail, 48 years old); "children - mom - dad" (Victoria, 35 years old); "my son is my family" (Irina, 52 years old); "family - children - health" (Igor, 53 years old; Ekaterina, 38 years old); "love husband - family" (Marina, 42 years old).

The first position of the associative array to the concept under study has also shown that happiness for some experiment participants was "life" (1\%, Lyudmila, 42 years old) and "euphoria" (1\%, Anastasia, 25 years). Happiness as a feeling and experience of one's being is often filled with strong emotions, for example: happiness as "sun" (5\%), "fire" (Diana, 18 years old) and "sea" (Tatyana, 43 years old). There are also tactile images ("warmth," Olga, 38 years old; Sophia, 19 years old; Natalia, 49 years old; "heat" Anastasia, 28 years old), color perception ("yellow," Irina, 47 years old), associations with the time of day ("dawn," Elena, 39 years old, "morning," Olga, 48 years old), positive feelings and states ("joy" (5\%), 
"harmony" (4\%), "calmness" (4\%), "conciliation" (3\%), "lightness" (2\%), "naturalness" ( $1 \%$, Tatyana, 51 years old), "silence" (1\%, Nadezhda, 55 years old), "peace" (1\%, Marina, 70 years) and "smile" (1\%, Galina, 47 years old).

Associations of happiness placed in the first position of the hierarchy of values can be connected with situations and their qualitative characteristics in which a person feels happy: "safety" (1\%, Nadezhda, 40 years old), "luck" (1\%, Nikita, 21 years old), "travel" (1\%), "horses" (1\%, Anna, 41 years old), "sleep" (1\%, Anastasia, 23 years old) and "money" (1\%, Petr, 39 years old). At the same time, the hierarchical chain of associations in the respondents' responses shows that the first value-based components of happiness are supplemented by the other components of this associative field, as well as the associative fields of "love," "family," "children" and associations with a pragmatic component [14].

While processing the empirical material, we have found questionnaires that described a strong experience of happiness through the hierarchical chain of value-based components that differed from most of the answers, for example, Tatyana (43 years old) called: sea; kiss; being creative; to hold the result of your creativity (book) in your hands; do not rush; to owe no one; to look out the window; to feel the moment; to behold true beauty and art, La Gioconda; travel, new impressions, people, culture; to do something that was considered insurmountable; self-overcoming; pride in oneself; to help a stranger; to stop being afraid of death, realizing that this is just a transition to another level.

This questionnaire of experiment participants indicated associations of happiness that structured various associative fields, in particular, "the state of happiness." From the philosophical viewpoint, many of these components are cognitive features of the conceptual field of "love" [15].

\section{Conclusion}

According to the experiment results, the nuclear group in the hierarchy of value-based components of the "happiness" concept in the Russian linguistic consciousness includes "love", "family" and "health". Other components of the hierarchical chains of associations in the questionnaires reveal the value-based attitude to life, being, mission in life, nature and animals.

The further description of hierarchical value-based components in the linguistic consciousness of the Russian speakers and representatives of other linguistic cultures will help identify the specifics of the "happiness" concept in various linguistic cultures.

\section{References}

1. Sh. K. Ri, Predstavlenie o schaste russkikh i koreitsev s raznym urovnem psikhologicheskogo blagopoluchiya [Ideas about happiness in Russia and South Korea with due regard to different levels of psychological well-being]: an extended abstract of thesis for a Candidate Degree in psychological sciences: 19.00.05. (YuzhnoSakhalinsk, 2016)

2. S.V. Khamidullina, Kontsept, 3, 371-375 (2013)

3. L.Z. Levit, SAGE Open, January-March, 1-7 (2014)

4. S.G. Vorkachev, Yazyk, Kommunikatsiya i Sotsial'naya Sreda [Language, Communication and Social Environment], 2, 4-18 (2020)

5. M. N. Le, Osobennosti yazykovoi reprezentatsii russkogo kontsepta "schaste": s pozitsii nositelya vetnamskoi kultury [The specific linguistic representation of the 
Russian concept of happiness: from the viewpoint of the Vietnamese]: thesis for a Candidate Degree in philological sciences: 10.02.01 (Moscow, 2011)

6. L.Z. Levit, Pedagogicheskoe Obrazovanie v Rossii [Pedagogical Education in Russia], 14,139-148 (2014)

7. M.A. Lysenko, Kontsept "schaste" i ego metaforicheskoe prelomlenie [The "happiness" concept and its metaphorical representation]: master's thesis. (UrFU im. B.N. Eltsina, Yekaterinburg, 2018)

8. E.A. Cherkashina, Vestnik TI, 2, 38-43 (2019)

9. P. Trudgill, Sociolinguistics: An introduction to language and society. $4^{\text {th }}$ Edition (Penguin, London, 2018)

10. W.H. Veith, Soziolinguistik [Sociolinguistics] (Gunter Narr Verlag, Tübingen, 2015)

11. E.S. Kubryakova, Voprosy Yazykoznaniya [Linguistics Issues], 4, 34-47 (1994)

12. A.A. Leontev, Osnovy psikholingvistiki [The foundations of psycholinguistics] (Smysl, Moscow, 1997)

13. V.P. Belyanin, Psikholingvistika [Psycholinguistics]: student's textbook (NGU Natali Nesterovoi, Moscow, 1999)

14. E. Kai, Russland verstehen [Understand Russia]. Available online: https://kaiehlers.de/2014/07/russland-verstehen/ . Accessed date: April 27, 2019.

15. D. Greetham, Textual Scholarship: An Introduction (Garland Publishing, New York, 2020) 